\title{
Economics of Different Genotypes of Cotton Planted under Various Planting Densities
}

\author{
Shakeel Ahmad Anjum1, Imran Khan1*, Ehsanullah1, Rashad Waseem Khan Qadri'2, \\ Muhammad Muzammil Jahangir ${ }^{2}$, Muqarrab Ali ${ }^{3}$, Mohsin Nawaz', Mohsin Bashir², \\ Muhammad Zain 1 \\ ${ }^{1}$ Department of Agronomy, University of Agriculture, Faisalabad, Pakistan \\ ${ }^{2}$ Institute of Horticultural Sciences, University of Agriculture, Faisalabad, Pakistan \\ ${ }^{3}$ Department of Agronomy, Muhammad Nawaz Shareef University of Agriculture, Multan, Pakistan \\ Email: ${ }^{*}$ agronomist786@hotmail.com
}

Received 19 May 2015; accepted 23 June 2015; published 26 June 2015

Copyright $@ 2015$ by authors and Scientific Research Publishing Inc.

This work is licensed under the Creative Commons Attribution International License (CC BY).

http://creativecommons.org/licenses/by/4.0/

(c) (i) Open Access

\begin{abstract}
A field experiment was conducted in order to evaluate the economics of different genotypes of cotton planted under various planting densities at Agronomic Research Area, University of Agriculture Faisalabad during the summer season in 2013. Sowing was done manually with the help of dibbling method on both sides of the bed in standing water, with bed distance of $75 \mathrm{~cm}$. The crop was sown in May and the experiment comprised of following FH-142, FH-114 at various densities $\left(S_{1}=10 \mathrm{~cm}, S_{2}=15 \mathrm{~cm}, S_{3}=20 \mathrm{~cm}, S_{4}=25 \mathrm{~cm}, S_{5}=30 \mathrm{~cm}\right)$. Data regarding net field benefit, benefit cost ratio, dominance analysis, and marginal rate of return were collected. The experimental results showed that maximum NFB of (Rs. 222,575), (Rs. 202,483) was achieved in FH-142 and FH114 when planted at a plant spacing of $20 \mathrm{~cm}$ and $15 \mathrm{~cm}$ respectively. While the maximum benefit cost ratio (BCR) of 1.76 was found in genotype FH-142 at plant spacing of 20 and $25 \mathrm{~cm}$ and FH114 depicted maximum BCR of 1.62 and 1.61 when planted at plant spacing of 15 and $20 \mathrm{~cm}$, respectively. Dominance analysis of FH-142 planted at 10 and $15 \mathrm{~cm}$ while FH-114 at plant spacing of 10,15 and $20 \mathrm{~cm}$ was dominated due to their lower net field benefits as compared to other treatments, while maximum marginal rate of return $(1494 \%, 788 \%)$ by planting $\mathrm{FH}-142, \mathrm{FH}-114$ was obtained at $30 \mathrm{~cm}$ and $25 \mathrm{~cm}$ recorded respectively.
\end{abstract}

\section{Keywords}

Cotton Genotypes, Spacings, Economic Analysis, Benefit Cost Ratio

\footnotetext{
${ }^{*}$ Corresponding author.
} 


\section{Introduction}

Cotton being an important cash crop of Pakistan contributes about $60 \%$ in the foreign exchange by export of various value added products (Iqbal et al., 2003) [1]. It plays an important role in economy of the world. Pakistan ranked fourth in cotton production worldwide, after China, India, and USA with total production of 13.0 million bales (2210 million kg), against the targeted 14.5 million bales, and third in the leading consumers throughout the world (Akhtar et al., 2010) [2].

Cotton crop is being influenced by various environmental factors. Optimum planting density can contribute in achieving maximum yield of cotton and it varies widely according to cropping system, environmental conditions and cultivars (Halemani and Hallikri, 2002) [3].

Among the various agronomic factors limiting seed cotton yield, low plant population and use of low potential genotypes are primarily important and thus responsible for low yield of cotton crop in the country. Adequate plant population per unit area of cotton seedlings is crucial to achieve high productivity and yield even at global level. Plant spacing has a key role in influencing the growth and yield characteristics of the crop and contributes $22.0 \%$ to $32.7 \%$ towards cotton yield (Mushtaq et al., 2010) [4].

Mostly, farmers maintain plant spacing and population in the field according to their conventional methods of planting instead of variety requirements and it consequently results in yield penalty. Cotton genotypes showed a diverse nature in their architecture that determines the optimum spacing necessary for it to get profitable yield (Ali et al., 2009) [5]. Plant arrangement can be adjusted simply with low cost but it has considerable impact on yield (Severino et al., 2006) [6]. However, the optimum plant spacing depends on characteristics of the genotype for example growth habit, height and plant architecture (Bezerra et al., 2009) [7].

In Pakistan, the recommended row-to-row distance for cotton crop is $75 \mathrm{~cm}$ but plant-to-plant distance varies from 15 to $25 \mathrm{~cm}$ with optimum plant population ranging from 60,000 to 75,000 plants $\cdot \mathrm{ha}^{-1}$.

Shah et al. (2005) [8] hypothesized that earliness seemed to be function of genotypes in cotton; however, the use of high plant density systems for production of cotton was initially conceived as a way to improve earliness and to decrease production costs.

The studies revealed that growth habit of a crop affects interaction between the plants and consequently needs to be accounted for recommending plant population. Moreover, it becomes imperative to develop such versatile techniques for planting of cotton that ensure efficient nutrient uptake and minimum mutual shading and inter plant competition. To overcome this problem, modern production technology emphasizes the role of proper plant spacing to ensure high productivity of cotton. So, keeping in view the importance of cotton crop the present study was undertaken to examine economics of various cotton genotypes which were planted at various planting densities.

\section{Material and Methods}

The study was carried out at the Agronomic Research Area, University of Agriculture, Faisalabad, Pakistan (31.25N, 73.09E) during 2013-2014. The experiment was laid out in randomized complete block design (RCBD) under factorial arrangement with three replications. Two factors were studied Factor A = Genotypes $\mathrm{V}_{1}=\mathrm{FH}-142$ (Spreading type) $\mathrm{V}_{2}=\mathrm{FH}-114$ (Erect type) Factor B was Plant to Plant Distance $\mathrm{S}_{1}=10 \mathrm{~cm}\left(133,333\right.$ plants $\cdot \mathrm{ha}^{-1}$ ),

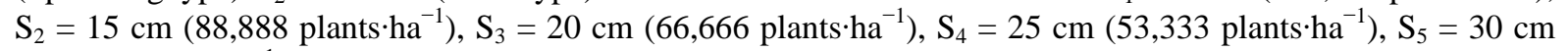
$\left(44,444\right.$ plants $\left.\cdot h^{-1}\right) .25 \mathrm{~kg} / \mathrm{ha}$ seed was used bed distance was $75 \mathrm{~cm}$. Fertilizers were applied at the rate of 200 and $115 \mathrm{~kg} \cdot \mathrm{ha}^{-1} \cdot \mathrm{N}$ and $\mathrm{P}_{2} \mathrm{O}_{5}$, respectively. 12 irrigations were given to fulfill requirement of crop. Different pesticides were used and also manually control of weeds was done.

The data collected were analyzed statistically using Fisher' analysis of variance technique and Least Significant Difference (LSD) test at 5\% level of probability was employed to compare the difference among treatments' means (Steel et al., 1997) [9].

\section{Result and Discussion}

\subsection{Net Field Benefits (NFB)}

Farmers are more interested in variability in benefits than yields, therefore net field benefits (NFB) were calculated against the variable costs. Table 1 reveals that maximum NFB of Rs. 222,575 was achieved in FH-142 when planted at a plant spacing of $20 \mathrm{~cm}$ against the minimum (Rs. 136,183) in plants spaced at $10 \mathrm{~cm}$ apart. 
Table 1. Effect of plant spacing on net returns, net field benefits and benefit cost ratio of two cotton genotypes.

\begin{tabular}{|c|c|c|c|c|c|c|c|c|}
\hline & Treatments & $\begin{array}{l}\text { Seed cotton } \\
\text { yield } \\
\left(\mathbf{k g}^{-1} \cdot \mathbf{h a}^{-1}\right)\end{array}$ & $\begin{array}{c}\text { Gross } \\
\text { income } \\
\left(\text { Rs}^{\prime} h \mathbf{h}^{-1}\right)\end{array}$ & $\begin{array}{c}\text { Variable } \\
\text { cost } \\
\left(\text { Rs}^{-} \mathbf{h a}^{-1}\right)\end{array}$ & $\begin{array}{l}\text { Total cost } \\
\left(\mathrm{Rs}^{-} \mathbf{h a}^{-1}\right)\end{array}$ & $\begin{array}{l}\text { Net field } \\
\text { benefits } \\
\text { (Rs·ha }^{-1} \text { ) }\end{array}$ & $\begin{array}{c}\text { Net } \\
\text { returns } \\
\left(\text { Rs}^{\prime} \cdot h^{-1}\right)\end{array}$ & $\begin{array}{c}\text { Benefit } \\
\text { cost ratio } \\
\left(\text { Rs}^{\prime} \cdot \mathbf{h a}^{-1}\right)\end{array}$ \\
\hline \multirow{5}{*}{$\begin{array}{l}\underset{I}{J} \\
\underset{I}{I} \\
{ }^{\prime \prime} \\
{ }^{-1}\end{array}$} & $S_{1}: 10 \mathrm{~cm} \times 75 \mathrm{~cm}$ & 2170.78 & 162808.5 & 26,625 & 142686.50 & 136183.50 & 20122.00 & 1.14 \\
\hline & $\mathrm{S}_{2}: 15 \mathrm{~cm} \times 75 \mathrm{~cm}$ & 2514.45 & 188583.8 & 22,975 & 139036.50 & 165608.75 & 49547.25 & 1.36 \\
\hline & $\mathrm{S}_{3}: 20 \mathrm{~cm} \times 75 \mathrm{~cm}$ & 3288.67 & 246650.3 & 24,075 & 140136.50 & 222575.25 & 106513.75 & 1.76 \\
\hline & $\mathrm{S}_{4}: 25 \mathrm{~cm} \times 75 \mathrm{~cm}$ & 3232.11 & 242408.3 & 22,050 & 138111.50 & 220358.25 & 104296.75 & 1.76 \\
\hline & $\mathrm{S}_{5}: 30 \mathrm{~cm} \times 75 \mathrm{~cm}$ & 2528.11 & 189608.3 & 17,525 & 133586.50 & 172083.25 & 56021.75 & 1.42 \\
\hline \multirow{5}{*}{ 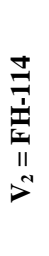 } & $S_{1}: 10 \mathrm{~cm} \times 75 \mathrm{~cm}$ & 2230.19 & 167264.3 & 26,925 & 142986.50 & 140339.25 & 24277.75 & 1.17 \\
\hline & $\mathrm{S}_{2}: 15 \mathrm{~cm} \times 75 \mathrm{~cm}$ & 3038.11 & 227858.3 & 25,375 & 141436.50 & 202483.25 & 86421.75 & 1.61 \\
\hline & $\mathrm{S}_{3}: 20 \mathrm{~cm} \times 75 \mathrm{~cm}$ & 2999.67 & 224975.3 & 22,725 & 138786.50 & 202250.25 & 86188.75 & 1.62 \\
\hline & $\mathrm{S}_{4}: 25 \mathrm{~cm} \times 75 \mathrm{~cm}$ & 2188.44 & 164133 & 17,100 & 133161.50 & 147033.00 & 30971.50 & 1.23 \\
\hline & $\mathrm{S}_{5}: 30 \mathrm{~cm} \times 75 \mathrm{~cm}$ & 1874.56 & 140592 & 14,450 & 130511.50 & 126142.00 & 10080.50 & 1.08 \\
\hline
\end{tabular}

Seed cotton rate $=3000 \mathrm{Rs} / 40 \mathrm{~kg}$; Total fixed cost $=$ Rs. 116061.5.

FH-114 showed maximum NFB of Rs. 202,483 at plant spacing of $15 \mathrm{~cm}$. However, minimum NFB of Rs. 126,142 was obtained in FH-114 at plant to plant distance of $30 \mathrm{~cm}$.

\subsection{Benefit Cost Ratio (BCR)}

Benefit cost ratio (BCR) is also important to farmers because they are interested in the increase in net returns with given increase in the total cost of production. The maximum benefit cost ratio (BCR) of 1.76 was found in spreading genotype FH-142 at plant spacing of 20 and $25 \mathrm{~cm}$ (Table 1). FH-114 depicted maximum BCR of 1.62 and 1.61 when planted at plant spacing of 15 and $20 \mathrm{~cm}$, respectively. This was due to its less cost of production and more gross income as compare to other treatments.

\subsection{Dominance Analysis}

As net field benefit (NFB) does not indicate the rate of return in relation to investment, final recommendation for the production technology cannot be specified only on the basis of NFB. Dominance and marginal analysis compares the variable costs with the gross margin, showing the increase in costs required to gain a given increase in gross margin. Treatments were first listed in increasing order of variable costs. Any treatment that had a total gross margin less than (or equal to) those of a treatment with lower total variable costs is dominated. Therefore, dominated treatments have a lower extra gross margin per unit of extra costs than other treatments (CIMMYT, 1988).

Data presented in Table 2 reveals that NFB of some treatments were less to those with lower cost comparative to an increase in variable cost among treatments. As a result these treatments were dominated (D). The remaining (un-dominated) treatments were further considered for the marginal analysis. It is clear from the Table 4.22 that FH-142 planted at 10 and $15 \mathrm{~cm}$ while FH-114 at plant spacing of 10, 15 and $20 \mathrm{~cm}$ were dominated due to their lower net field benefits as compared to the preceding treatment.

\subsection{Marginal Analysis}

Marginal analysis was calculated to check the economic impact of plant to plant spacing on two cotton genotypes. This analysis assists the farmers to get the maximum benefit from the inputs by using the limited resources. Marginal analysis formed the basis of economic reasoning and it showed the effects of a small change in the control variable. As real differences were found in the yield among different treatments, therefore marginal analysis was done. Table 3 shows the marginal analysis of un-dominated treatments. Maximum marginal rate of return (1494\%) was obtained by planting FH-142 at plant spacing of $30 \mathrm{~cm}$. FH-114 recorded maximum marginal rate of return (788\%), when planted at a plant to plant distance of $25 \mathrm{~cm}$. 
Table 2. Effect of plant spacing on dominance analysis of two cotton genotypes.

\begin{tabular}{|c|c|c|}
\hline Treatments & Cost that vary $\left(\mathrm{PRs}^{\prime} \mathrm{ha}^{-1}\right)$ & Net field benefits (PRs·ha ${ }^{-1}$ ) \\
\hline $\mathrm{V}_{2} \mathrm{~S}_{5}: 30 \mathrm{~cm} \times 75 \mathrm{~cm}$ & 14,450 & 126,142 \\
\hline $\mathrm{V}_{2} \mathrm{~S}_{4}: 25 \mathrm{~cm} \times 75 \mathrm{~cm}$ & 17,100 & 147,033 \\
\hline $\mathrm{V}_{1} \mathrm{~S}_{5}: 30 \mathrm{~cm} \times 75 \mathrm{~cm}$ & 17,525 & 172,083 \\
\hline $\mathrm{V}_{1} \mathrm{~S}_{4}: 25 \mathrm{~cm} \times 75 \mathrm{~cm}$ & 22,050 & 220,358 \\
\hline $\mathrm{V}_{2} \mathrm{~S}_{3}: 20 \mathrm{~cm} \times 75 \mathrm{~cm}$ & 22,725 & $202,250 \mathbf{D}$ \\
\hline $\mathrm{V}_{1} \mathrm{~S}_{2}: 15 \mathrm{~cm} \times 75 \mathrm{~cm}$ & 22,975 & $165,609 \mathbf{D}$ \\
\hline $\mathrm{V}_{1} \mathrm{~S}_{3}: 20 \mathrm{~cm} \times 75 \mathrm{~cm}$ & 24,075 & 222,575 \\
\hline $\mathrm{V}_{2} \mathrm{~S}_{2}: 15 \mathrm{~cm} \times 75 \mathrm{~cm}$ & 25,375 & $202,483 \mathbf{D}$ \\
\hline$V_{1} S_{1}: 10 \mathrm{~cm} \times 75 \mathrm{~cm}$ & 26,625 & $136,183 \mathbf{D}$ \\
\hline $\mathrm{V}_{2} \mathrm{~S}_{1}: 10 \mathrm{~cm} \times 75 \mathrm{~cm}$ & 26,925 & $140,339 \mathbf{D}$ \\
\hline
\end{tabular}

$\mathrm{D}=$ Dominated.

Table 3. Effect of plant spacing on marginal analysis of two cotton genotypes.

\begin{tabular}{|c|c|c|c|c|c|}
\hline Treatments & $\begin{array}{l}\text { Cost that vary } \\
\left(\text { PRs }^{\prime} \cdot h^{-1}\right)\end{array}$ & $\begin{array}{l}\text { Marginal cost } \\
\text { that vary }\left(\mathrm{PRs}^{2} \cdot \mathrm{ha}^{-1}\right)\end{array}$ & 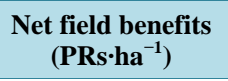 & $\begin{array}{c}\text { Marginal net } \\
\text { benefits (PRs:ha }{ }^{-1} \text { ) }\end{array}$ & $\begin{array}{l}\text { Marginal rate } \\
\text { of return (\%) }\end{array}$ \\
\hline $\mathrm{V}_{2} \mathrm{~S}_{5}: 30 \mathrm{~cm} \times 75 \mathrm{~cm}$ & 14,450 & - & 126,142 & - & - \\
\hline $\mathrm{V}_{2} \mathrm{~S}_{4}: 25 \mathrm{~cm} \times 75 \mathrm{~cm}$ & 17,100 & 2650 & 147,033 & 20,891 & 788 \\
\hline $\mathrm{V}_{1} \mathrm{~S}_{5}: 30 \mathrm{~cm} \times 75 \mathrm{~cm}$ & 17,525 & 3075 & 172,083 & 45,941 & 1494 \\
\hline $\mathrm{V}_{1} \mathrm{~S}_{4}: 25 \mathrm{~cm} \times 75 \mathrm{~cm}$ & 22,050 & 7600 & 220,358 & 94,216 & 1240 \\
\hline $\mathrm{V}_{1} \mathrm{~S}_{3}: 20 \mathrm{~cm} \times 75 \mathrm{~cm}$ & 24,075 & 9625 & 222,575 & 96,433 & 1002 \\
\hline
\end{tabular}

$\mathrm{V}_{1}=\mathrm{FH}-142 ; \mathrm{V}_{2}=\mathrm{FH}-114$.

It is evident from the results that farmers with poor resources can accomplish maximum benefits by planting FH-142 at plant spacing of $30 \mathrm{~cm}$ and FH-114 at $25 \mathrm{~cm}$, respectively. Farmers with better resources can move towards planting cotton at plant to plant distance of 20 and $25 \mathrm{~cm}$ in case of FH-142 and $30 \mathrm{~cm} \mathrm{for} \mathrm{FH-114,} \mathrm{re-}$ spectively.

\section{Conclusion}

Spreading genotype FH-142 gave higher benefit cost ratio (1.76) at plant spacing of 20 and $25 \mathrm{~cm}$. FH-114 depicted maximum BCR (1.62 and 1.61) when planted at plant spacing of 15 and $20 \mathrm{~cm}$, respectively. Maximum marginal rate of return (1494\%) was obtained by planting FH-142 at plant spacing of $30 \mathrm{~cm}$. FH-114 recorded maximum marginal rate of return (788\%), when planted at the plant-to-plant distance of $25 \mathrm{~cm}$.

\section{References}

[1] Iqbal, M., Chang, M.A., Jabbar, A., Iqbal, M.Z., Hassan, M. and Islam, N. (2003) Inheritance of Earliness and Other Characters in Upland Cotton. Journal of Biological Sciences, 3, 585-590. http://dx.doi.org/10.3923/jbs.2003.585.590

[2] Akhtar, K.P., Khan, M.K.R., Ahmad, M., Sarwar, N. and Ditta, A. (2010) Short Communication. Partial Resistance of a Cotton Mutant to Cotton Leaf Curl Burewala Virus. Spanish Journal of Agricultural Research, 8, 1098-1104. http://dx.doi.org/10.5424/sjar/2010084-1404

[3] Halemani, H.L. and Hallikeri, S.S. (2002) Response of Compact and Early Maturing Cotton Genotypes to Plant Population Levels under Rainfed Conditions. Journal of Cotton Research Development, 16, 143-146.

[4] Ali, M., Ali, L., Sattar, M. and Ali, M.A. (2010) Response of Seed Cotton Yield to Various Plant Populations and Planting Methods. Journal of Agricultural Research, 48, 163-169. 
[5] Ali, H., Afzal, M.N., Ahmad, S. and Muhammad, D. (2009) Effect of Cultivars and Sowing Dates on Yield and Quality of Gossypium hirsutum L. Crop. Journal of Food, Agriculture and Environment, 7, 244-247.

[6] Severino, L.S., Coelho, D.K., Moraes, C.R.D.A., Gondim, T.M.D.S. and Do Vale, L.S. (2006) Otimização do espaçamento de plantio para a mamoneira cultivar BRS Nordestina. Revista Brasileira de Oleaginosas e Fibrosas, 10, 993999.

[7] Bezerra, A.A.C., Tavora, F.J.A.F., Freire Filho, F.R. and Ribeiro, V.Q. (2009) Características de dossel e de rendimento em feijão-caupi ereto em diferentes densidades populacionais. Pesquisa Agropecuária Brasileira, 44, 12391245. http://dx.doi.org/10.1590/S0100-204X2009001000005

[8] Shah, M.K.N., Malik, S.A. and Saleem, M. (2005) Stability of Cotton Cultivars for Early Crop Maturity across Variable Plant Spacing and Sowing Times. Pakistan Journal of Botany, 37, 345.

[9] Steel, R.G.D., Torrie, J.H. and Dicky, D.A. (1997) Principles and Procedures of Statistics; A Biometrical Approach. 3rd Edition, McGraw Hill, Inc. Book Co., New York, 352. 